\title{
LIETUVOS GYVENTOJŲ NUOMONĖS APIE PRIDĖTINIO CUKRAUS IR SALDIKLIŲ VARTOJIMĄ TYRIMAS
}

\author{
Rimantas Stukas, Rokas Arlauskas, Ieva Lingytė, Valerij Dobrovolskij, Donatas Austys \\ Vilniaus universiteto Medicinos fakulteto Sveikatos mokslu institutas
}

Raktažodžiai: cukrus, saldikliai, Lietuvos gyventojai, suaugusieji, nuomonè.

\section{Santrauka \\ Sprendžiant antsvorio, nutukimo ir su tuo susijusių ligų problemas, Lietuvoje ir kitose pasaulio valsty- bèse siekiama sumažinti maisto produktuose esan- čio pridètinio cukraus kiekị. Tikètina, kad mažinant cukraus vartojimą, gali išaugti cukraus pakaitalų - saldiklių vartojimas. Jie, kaip ir pridètinis cukrus, siejami su įvairiapusiu poveikiu sveikatai. Cukraus ir saldiklių vartojimo paplitimas pagal socialinius ir demografinius rodiklius skiriasi ịvairiose pasaulio valstybėse. Trūksta duomenų apie saldiklių vartojimo paplitimą bei požiūrị i juos Lietuvoje, todèl tyrimo tikslas - atsižvelgiant ị socialines ir demografines charakteristikas, įvertinti saldiklių vartojimo papli- timą tarp Lietuvos gyventojų. Tikslui pasiekti suda- ryta Lietuvos populiaciją reprezentuojanti imtis. Iš viso tyrime dalyvavo 1008 respondentai nuo $18 \mathrm{iki}$ 75 metų. Duomenys buvo renkami vykdant anketinę apklausą. Analizuotos gyventojų socialinès ir demo- grafinès charakteristikos (lytis, amžius, gyvenamosios vietos tipas, užimtumas, gaunamos pajamos, šeiminè padètis ir išsimokslinimas), maisto produktų pasirin- kimo, cukraus ir saldiklių vartojimo paplitimo ypa- tumai, žinios ir nuomonè apie saldiklius.}

Rezultatai parodè, kad gyvenamosios vietos tipas, igytas išsimokslinimas bei lytis - dažniausi veiksniai, lemiantys etikečių skaitymo, cukraus ir saldikliu vartojimo netolygumus. Didesnè dalis kaimo gyventojų neskaitė etikečių, maisto produktus rinkosi pagal kainą, nesidomèjo jų sudètimi (atitinkamai 20,4\% prieš $12,3 \%, 28,3 \%$ prieš $17,3 \%, 35,5 \%$ prieš $20,4 \%$, $\mathrm{p}<0,05)$. Miesto gyventojai dažniau buvo linkę išbandyti naujus produktus, geriau nei kaimo gyventojai vertino natūralių saldiklių poveikị organizmui (atitinkamai $17,3 \%$ prieš $9,7 \%, 32,2 \%$ prieš $23,7 \%$, $\mathrm{p}<0,05)$. Žemesnio išsimokslinimo asmenys dažniau nesidomejo vartojamų produktų sudètimi, dažniau manè, kad natūralūs saldikliai neturi jokio poveikio organizmui (atitinkamai $27,9 \%$ prieš $16,0 \%, 12,0 \%$ prieš $8,2 \%, p<0,05)$. Aukštesnio išsimokslinimo respondentai dažniau skaitè maisto produktų etiketes, buvo linkę išbandyti naujus produktus, maisto produktus rinkosi atsižvelgdami i jų kokybę (atitinkamai $36,4 \%$ prieš $22,4 \%, 20,4 \%$ prieš $13,3 \%, 12,6 \%$ prieš $10,2 \%, p<0,05)$. Vyrai dažniau neskaitè etikečių, nesidomèjo jų sudètimi (atitinkamai 21,2\% prieš $9,0 \%, 28,9 \%$ prieš $20,9 \%, p<0,05)$. Moterys dažniau buvo linkusios kartais išbandyti naujas maisto prekes $(49,5 \%$ prieš $42,1 \%, p<0,05)$. Medus, fruktozè ir sacharinas - labiausiai Lietuvoje paplitę saldikliai (atitinkamai, 78,1\%, 43,4\% ir 30,9\%). Stevijos nežinojo 45,7\% apklaustujų. Nustatyta, kad gyvenamosios vietos tipas, igytas išsimokslinimas bei lytis - dažniausi veiksniai, lemiantys etikečių skaitymo, cukraus ir saldiklių vartojimo netolygumus. Dauguma gyventojų kaip žinomus ir ragautus saldiklius nurodė medų ir fruktozę, o svetur dažnai vartojamo saldiklio - stevijos nežinojo beveik pusė Lietuvos gyventojų.

\section{Ivadas}

Pasaulio sveikatos organizacija (toliau - PSO) ragina kurti veiklos programas, skatinančias mažinti antsvorio, nutukimo ir su tuo susijusių ligų problemas. Siūloma iki 2020 metų griežtai apriboti pridètinio cukraus naudojimą maisto gamybos įmonèse bei sumažinti pridètinio cukraus kiekị iki bent 10 proc. dienos kalorijų normos [1]. 2014 metais Lietuvos Respublikos Seimas prièmè nutarimą dèl Lietuvos sveikatos 2014-2025 metų programos patvirtinimo, skatinanti maisto produktų gamybos įmones mažinti cukraus kiekị produktuose, o kur tai imanoma, pateikti informaciją apie maisto produktų sudètị suprantamai, aiškiai ir matomoje vie- 
toje [2]. Tikètina, kad igyvendinant šias iniciatyvas, cukraus vartojimas sumažès, tačiau gali išaugti cukraus pakaitalų saldiklių vartojimas [3-5]. Saldikliai - cukraus neturinčios maisto medžiagos, naudojamos išgauti saldų skoni [6]. Saldikliai tampa vis aktualesni visuomeneje, bandant sumažinti pridètinio cukraus žalą organizmui.

Nors cukrus yra lengvai įsisavinamas energijos šaltinis, natūraliai randamas daugelyje vaisių ir daržovių, tačiau pridètinis cukrus, naudojamas maisto produktų gamyboje, siejamas su daugeliu sveikatos sutrikimų: dantų ėduonimi, antsvoriu ir nutukimu, širdies ir kraujagyslių ligomis, II tipo cukriniu diabetu, metaboliniu sindromu, nealkoholiniu kepenų suriebejjimu [7]. Saldikliai, kaip ir pridètinis cukrus, siejami su įvairiapusiu poveikiu sveikatai. Dirbtiniai saldikliai buvo sukurti siekiant sumažinti nutukimą ir atsparumą insulinui, jais pakeičiant pridètinio cukraus vartojimą. Seniausiai žinomas saldiklis sacharinas neturi kalorijų, tačiau 1977 m. atlikti tyrimai su pelemis parodè, kad šio saldiklio vartojimas didelėmis dozėmis gali sukelti šlapimo pūslès věžĭ. Kancerogeninis sacharino poveikis žmonèms nèra įrodytas, nes sacharino kiekis maiste apribotas iki $5 \mathrm{mg}$ vienam kg kūno masès [8]. Aspartamas - kitas dažnai vartojamas dirbtinis cukraus pakaitalas, priešingai nei sacharinas, turi kalorijų (4 kcal/g), yra mažiau saldus, neturi kartaus skonio [8]. Vartojant ši saldikli gerokai didesnèmis dozėmis nei rekomenduojamos, iškyla oksidacinio streso rizika [9], galinti nulemti kognityvinius ir elgesio sutrikimus, kai dèl oksidacinio streso padidejja kortizolio ir laisvujų radikalų koncentracija kraujyje [10]. Remiantis atliktais tyrimais, aspartamas gali padidinti metabolinio sindromo riziką, nulemti žarnyno mikrobiotos pakitimus, sukelti alkio jausmą ir dèl to skatinti nutukimą [11,12]. Mokslinèje literatūroje stebima daug prieštaravimų dẻl saldiklių poveikio: daugelis tyrimų rodo, kad mažai kalorijų turinčiu saldiklių vartojimas nedaro didelès įtakos apetitui ar alkiui, tačiau yra tyrimų, rodančių, kad saldiklių vartojimas gali padidinti apetitą ar alkị, arba atvirkščiai - sumažinti šiuos organizmo poreikius [13].

Natūralūs saldikliai, tokie kaip medus, fruktozè, stevija, kukurūzų sirupas yra kaloringesni ir brangesni, negu dirbtiniai. Fruktozè - tai monosacharidas, randamas daugelyje vaisių ir daržovių. Ji skatina B grupès vitaminų ir geležies įsisavinimą, veikia kaip ilgalaikès energijos šaltinis [14]. Fruktozės vartojimas dideliais kiekiais gali nulemti medžiagų apykaitos sutrikimus [15], nealkoholinę kepenų steatozę, dislipidemiją [16]. Stevija, priešingai fruktozei, turi mažiau kalorijų, susijusi su mažesniu kraujospūdžiu bei mažesne gliukozès koncentracija kraujyje [17].

Saldiklių vartojimas tarp ịvairių gyventojų grupių gali skirtis. Jungtinèse Amerikos valstijose (toliau - JAV) saldi- klius dažniau vartoja vyresni žmonès bei asmenys, turintys antsvorio ar nutukę. Be to, didesnis saldiklių vartojimo paplitimas JAV susijęs su didesnèmis pajamomis bei aukštesniu išsimokslinimu [4]. Saldiklių ir pridėtinio cukraus vartojimui gali turèti įtakos tai, ar žmonès perskaito etiketèse pateiktą informaciją [18]. Trūksta duomenų apie saldiklių vartojimo paplitimą bei požiūrị i juos Lietuvoje.

Tyrimo tikslas - atsižvelgiant ị socialines ir demografines charakteristikas, ịvertinti saldiklių vartojimo paplitimą tarp Lietuvos gyventojų.

\section{Darbo medžiaga ir metodika}

Tyrimo duomenys rinkti 2019 metų kovo mènesị. Tiriamujjų imtị sudare Lietuvos gyventojai nuo 18 iki 75 metų. Reprezentatyvios imties sudarymui naudotas daugiapakopès stratifikuotos tikimybinès atrankos metodas. Kiekvienas šalies namų ūkis turejo vienodas galimybes patekti ị tyrimo imtị. Duomenys buvo renkami vykdant anketinę apklausą. Apklausa vykdyta dviem būdais: 60 proc. tiriamuju pagal parengtus klausimus buvo apklausti profesionalių apklausèjų kompiuterizuoto asmeninio interviu būdu, kiti 40 proc. tyrimo dalyvių jiems patogiu metu savarankiškai atsake i elektronines anketas. Buvo užtikrintos reikiamos priemonès, kad klausimyno nebūtų galima užpildyti kelis kartus.

Tyrimui naudotas klausimynas, kurị sudare 7 klausimai apie socialines ir demografinines respondentų charakteristikas (lytị, amžių, gyvenamosios vietos tipą, užimtumą, vienam namų ūkio nariui per mėnesị tenkančias pajamas, šeiminę padètį, išsimokslinimą); 3 klausimai apie maisto produktų pasirinkimo ypatumus (,Ar renkantis maisto prekes parduotuveje skaitote jų sudètį?“, „Ar esate linkęs(-usi) parduotuvejje pamatytą naują, dar nebandytą maisto prekę, ją išbandyti?“", „Kuris iš nurodytų teiginiu geriausiai apibūdina, kaip renkatès maisto produktus?"); 4 klausimai, skirti saldiklių vartojimo paplitimui nustatyti (,Kuo paprastai saldinate kavą ar arbatą?“", „Kaip dažnai vartojate maisto produktus ar gèrimus, kuriuose yra saldiklių?““, „Kuriuos iš šių saldiklių esate ragavęs (-usi)?“, „Kaip dažnai vartojate maisto produktus, kurių sudètyje yra stevijos?"); 2 klausimai žinių apie saldiklius ịvertinimui (,Kokius natūralius saldiklius žinote?“, „Kurie iš išvardytų saldiklių yra natūralūs?“); 2 klausimai nuomonei apie saldiklius įvertinti (,Kaip vertinate šiuos saldiklius?“, „Kaip manote, kokị poveiki jūsų organizmui turi natūralūs saldikliai?").

Socialinès ir demografinès respondentų charakteristikos analizuotos kaip dvinariai kintamieji. Kadangi respondentų pasiskirstymas pagal amžių neatitiko normalumo dèsnio, imtis buvo padalinta ị dvi grupes pagal amžiaus medianą: iki 45 metų bei 46 metų ir vyresnius. Pagal išsimokslinimą 
apklaustieji suskirstyti ị igijusius aukštaji (aukštasis, nebaigtas aukštasis) ir žemesnị (vidurinį, specialuji vidurinị ir nebaigtą vidurinị). Pagal vienam namų ūkio nariui per mėnesị tenkančias pajamas, respondentai suskirstyti į dvi grupes: gaunantys iki 500 eurų ir gaunantys daugiau kaip 500 eurų. Pagal užimtumą apklaustieji buvo suskirstyti ị nedirbančius (moksleiviai, studentai, pensininkai, namų šeimininkès, bedarbiai) ir dirbančius (aukščiausio, vidutinio lygio vadovai, specialistai, tarnautojai, darbininkai, techniniai darbuotojai, smulkūs verslininkai, ūkininkai). Pagal šeiminę padètị analizuotos vienų gyvenančių (nevedusių/netekejjusių) ir turinčių partnerị (vedusių/ištekejjusių ar gyvenančių neregistruotoje santuokoje) respondentų grupės. Pagal gyvenamają vietą respondentai suskirstyti ị miestų (didžiujų, kitų miestų, rajonų) ir kaimo vietovès gyventojus.

Shapiro-Wilk testu buvo patikrintas skirstinių normalumas. Pagal normalųji dèsnị pasiskirsčiusių skirstinių dispersijų homogeniškumo patikrinimui naudotas Bartlett testas. Pagal normalųjị dėsnị pasiskirsčiusių skirstinių, kurių dispersijos buvo lygios, vidurkių palyginimui naudotas Student t-testas. Pagal normalųjị dèsnị pasiskirsčiusių skirstinių, kurių dispersijos statistiškai reikšmingai skirtųsi, nebuvo. Skirstinių, kurie nebuvo pasiskirstę pagal normalujji dèsnį, vidurkiu palyginimui buvo naudojamas Wilcoxon (arba Mann-Whitney U) testas. Nominaliųjų kintamujjų palyginimui skirtingose grupèse buvo naudojamas $\chi^{2}$ kriterijus. Statistiniams skaičiavimams pasirinktas reikšmingumo lygmuo $\alpha=0,05$. Statistiškai reikšmingai besiskiriančiomis grupėmis laikytos tos, kur $p \leq 0,05$. Skaitiniams kintamiesiems buvo

1 lentelè. Respondentų pasiskirstymas pagal socialines ir demografines charakteristikas.

\begin{tabular}{|c|c|c|}
\hline \multicolumn{2}{|l|}{ Kintamieji } & \multirow{2}{*}{$\begin{array}{c}\begin{array}{c}\text { Santyki- } \\
\text { nis daž- } \\
\text { nis, \% }\end{array} \\
45,9 \\
\end{array}$} \\
\hline Lytis $(\mathrm{n}=1008)$ & vyras & \\
\hline & moteris & 54,1 \\
\hline \multirow[t]{2}{*}{ Amžius ( $\mathrm{n}=1008$ ) } & iki 45 metų & 49,0 \\
\hline & nuo 45 metu & 51,0 \\
\hline \multirow{2}{*}{$\begin{array}{l}\text { Gyvenviete } \\
(\mathrm{n}=1008)\end{array}$} & miestas & 72,3 \\
\hline & kaimas & 27,7 \\
\hline \multirow{2}{*}{$\begin{array}{l}\text { Užimtumas } \\
(\mathrm{n}=1002)\end{array}$} & dirbantys & 73,9 \\
\hline & nedirbantys & 26,1 \\
\hline \multirow[t]{2}{*}{ Pajamos $(\mathrm{n}=869)$} & iki 500 euru & 25,1 \\
\hline & per 500 euru & 74,9 \\
\hline \multirow{2}{*}{$\begin{array}{l}\text { Šeiminè padètis } \\
(\mathrm{n}=999)\end{array}$} & nevedęs/netekèjusi & 26,0 \\
\hline & $\begin{array}{l}\text { vedęs/ištekèjusi, gyvena nere- } \\
\text { gistruotoje santuokoje }\end{array}$ & 74,0 \\
\hline \multirow{2}{*}{$\begin{array}{l}\text { Išsimokslinimas } \\
(\mathrm{n}=1004)\end{array}$} & aukštasis ir nebaigtas aukštasis & 26,8 \\
\hline & žemesnis & 73,2 \\
\hline
\end{tabular}

apskaičiuoti vidurkiai, kurie pateikiami tokia forma: vidurkis \pm standartinis nuokrypis.

\section{Tyrimo rezultatai}

Iš viso tyrime dalyvavo 1008 respondentai. Jų daugumą sudare mieste gyvenantys, dirbantys, poroje gyvenantys ir žemesnio išsimokslinimo asmenys. Daugumos respondentų namų ūkiuose vienam nariui teko daugiau nei 500 eurų per ménesį. Vyrai ir moterys sudare panašias imties dalis. Tiriamụjų amžiaus mediana buvo 45 (32-56) metai (1 lentelè).

Tyrimo rezultatai atskleide, kad rinkdamiesi maisto produktus, kai kurie respondentai $(14,6 \%$, iš jų $21,2 \%$ vyrų ir $9,0 \%$ moterų) visai neskaite jų etikečių, kiti $(21,5 \%)$ skaitė pavieniais atvejais arba kartais $(37,7 \%)$. Dažnai etiketes skaitè kone trečdalis respondentų $(26,2 \%$, iš jų $33,6 \%$ moterų ir $17,5 \%$ vyrų). Maisto produktų sudètimi ženkliai labiau domejjosi moterys ( $p<0,001)$, dažniau etiketes skaitė aukštesnio, nei žemesnio išsimokslinimo respondentai (atitinkamai $36,4 \%$ ir 22,4\%). Etikečių neskaitè didesnè dalis kaimo nei miesto gyventojų (atitinkamai 20,4\% ir 12,3\%). Rinkdamiesi maisto produktus, jų etikečių dažniau visai neskaitè nedirbantys respondentai $(20,2 \%$, lyginant su $12,7 \%$ dirbančiujų).

Dauguma respondentų $(46,1 \%)$ nurodè, kad kartais yra linkę išbandyti naujas maisto prekes, perpus mažiau $(23,2 \%)$ jas išbando retai, o mažuma $(15,5 \%)$ nebuvo linkusi išbandyti naujų maisto prekių. Tik maža dalis $(15,2 \%)$ nurodé, kad naujas prekes išbando dažnai. Dažniau išbandyti naujus produktus buvo linkę jaunesni respondentai (18\%), aukštesnio išsimokslinimo $(20,4 \%)$, dirbantys $(16,8 \%)$, gaunantys mažiau pajamų (16\%) bei didmiesčių gyventojai (17,3\%). Kartais išbandyti naujas maisto prekes labiau buvo linkusios moterys $(49,5 \%)$, negu vyrai $(42,1 \%)$.

Dauguma respondentų $(68,8 \%)$, rinkdamiesi maisto produktus, ieškojo geriausios kainos ir kokybės santykio, kiti tyrimo dalyviai ieškojo mažiausios kainos (20,3 proc.) arba geriausios kokybès $(10,8$ proc). Nurodydami produktų pasirinkimo prioritetus, kokybę dažniau ịvardijo aukštesnio išsimokslinimo, dirbantys, didmiesčių gyventojai, 45 metų ir jaunesni respondentai (atitinkamai 12,6\% prieš 10,2\%, 11,8\% prieš $8,4 \%, 11,5 \%$ prieš $9 \%, 11,7 \%$ prieš $9,9 \%$ ). Mažiausia kaina dažniau buvo pagrindinis vyresnio amžiaus respondentų, kaimo gyventojų bei nedirbančių asmenų (atitinkamai $25,9 \%$ prieš $14,6 \%, 28,3 \%$ prieš $17,3 \%, 25,6 \%$ prieš $18,5 \%$ ) kriterijus.

Kavai ir arbatai saldinti daugiau kaip pusè $(55,3 \%)$ Lietuvos gyventojų vartojo cukrų, nedaugelis $(10,1 \%)-$ medų, kai kurie $(2,5 \%)$ vartojo saldiklius. Cukrų dažniau vartojantys nurodè vyrai (atitinkamai $62,9 \%$ prieš $48,8 \%$ ) 
ir žemesnio išsimokslinimo asmenys (atitinkamai 57,4\% prieš 49,1\%). Visiškai nesaldinančios kavos ar arbatos dažniau teigė moterys ( $37,1 \%$ prieš $22,2 \%$ ), ne vieni gyvenantys asmenys $(31,3 \%$ prieš $24,7 \%)$ ir aukštesnio išsimokslinimo respondentai $(36,8 \%$ prieš $27,9 \%)$. Medus buvo populiaresnis labiau išsimokslinusių žmonių grupeje bei tarp vienų gyvenančių asmenų (atitinkamai $11,2 \%$ prieš $9,8 \%$, $12,8 \%$ prieš $9,3 \%$ ).

Daugiausia respondentų $(33,9 \%)$ nurodè, kad bent kartą per savaitę vartojo produktus su saldikliais, kai kurie $(23,5 \%)$ tokių produktų nevartojo, ketvirtis $(24,6 \%)$ negalejo atsakyti, nes nežinojo, kurie jų vartojami produktai turi saldiklių. Maisto produktus ir gerimus su saldikliais dažniau vartojo vieni gyvenantys asmenys (kasdien $16,3 \%$ prieš $9,6 \%$ ) bei jaunesnio amžiaus respondentai (kasdien $14,8 \%$ prieš $7 \%$ ). Dauguma apklaustųjų: kaimų gyventojai $(35,5 \%)$, vyrai $(28,9 \%)$, daugiau kaip 45 metų gyventojai (28\%), žemesnio išsimokslinimo $(27,9 \%)$ bei gaunantys mažai pajamų (26,4\%), nežinojo, ar dažnai vartojo saldiklius, nes nesidomèjo, kurie jų vartojami produktai turi saldiklių.

Kaip natūralius saldiklius respondentai įvardijo medų $(51,8 \%)$, fruktozę (13\%), steviją $(8,4 \%)$, cukrų $(8,8 \%)$, sachariną $(5,6 \%)$, aspartamą $(1,3 \%)$, kukurūzų sirupą $(0,4 \%)$, sukralozę $(0,4 \%)$, kitus saldiklius $(36,4 \%)$. Medų prie natūralių saldiklių dažniau priskyrè kaimo gyventojai, dirbantys ir aukštaji išsimokslinimą ịgiję asmenys (atitinkamai $57 \%$ prieš $49,8 \%$,
$54,6 \%$ prieš 44,3\%, 58\% prieš 49,4\%). Fruktozę, kaip natūralų saldiklį, dažniau minèjo dirbantys asmenys (14,2\%), negu nedirbantys $(9,2 \%)$. Steviją dažniau ịvardijo moterys, didmiesčiu gyventojai bei labiau išsimokslinę apklaustieji (atitinkamai $11,4 \%$ prieš $5 \%$, $10,3 \%$ prieš $3,6 \%, 13,8 \%$ prieš $6,5 \%$ ). Cukrų natūraliu saldikliu dažniau laikè vyrai, nei moterys (atitinkamai $11,9 \%$ prieš $6,2 \%$ ). Kitus saldiklius prie natūralių dažniau priskyre vyrai ir vieni gyvenantys asmenys (atitinkamai $38,7 \%$ prieš $30,5 \%, 43,2 \%$ prieš $34,4 \%$ ).

Beveik pusè Lietuvos gyventojų nežinojo saldiklio stevijos (45,7\%), kiti (22,5\%) nurode jos nevartojantys. Tik keletas apklaustujų $(4,3 \%)$ produktus su stevija vartojo bent kartą per savaitę. Moterys, dažniau nei vyrai, miesto gyventojai dažniau nei kaimo, gaunantys didesnes pajamas, dažniau nei gaunantys mažesnes, vartojo steviją bent kartą per savaitę (atitinkamai $5,5 \%$ prieš $2,7 \%, 4,7 \%$ prieš $3,2 \%, 7,4 \%$ prieš $3,5 \%$ ). Žemesnio išsimokslinimo apklaustieji dažniau nežinojo šio saldiklio (49\% prieš 37,2\%). Vyresni nei 45 metų respondentai dažniau nevartojo stevijos (atitinkamai 24,9\% prieš $20 \%$ ).

Kai kurie apklaustieji buvo neigiamos nuomonès apie steviją (4,0\%), apie aspartamą (10,7\%), apie sachariną (14,1\%), apie fruktozę $(4,0 \%)$ ir apie sukralozę $(6,9 \%)$. Geriausiai žinoma (jos nežinojo tik $9,8 \%$ respondentų) ir pozityviai vertinama $(27,9 \%)$ - fruktozè. Teigiamai buvo vertinama stevija $(18,4 \%)$, aspartamas $(4,8 \%)$, sacharinas (14,0\%), sukralozė $(6,8 \%)$. Teigiamai steviją vertino moterys, didmiesčių gyventojai bei išsimokslinę asmenys (atitinkamai $22,6 \%$ prieš $13,4 \%, 20,7 \%$ prieš $12,2 \%, 21,9 \%$ prieš $17,0 \%$ ). Aspartamą daugiausiai neigiamai vertino miesto gyventojai ir aukštesni

2 lentelè. Cukraus ir saldiklių vartojimas pagal socialinius ir demografinius rodiklius.

\begin{tabular}{|c|c|c|c|c|c|c|c|}
\hline \multirow[t]{2}{*}{ Kintamieji } & \multicolumn{7}{|c|}{$\begin{array}{l}\text { Kintamujjų p reikšmės pagal socialinius ir } \\
\text { demografinius rodiklius }\end{array}$} \\
\hline & 氖 & 浔 & $\sum_{0 \infty}^{\frac{1}{0}} \cdot \frac{\pi}{\frac{\pi}{2}}$ & $\stackrel{\stackrel{E}{\Xi}}{\stackrel{\Xi}{\Xi}}$ & 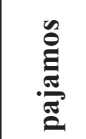 & 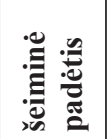 & 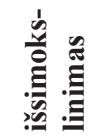 \\
\hline $\begin{array}{l}\text { Sudėties skaitymas, renkantis } \\
\text { maisto prekes }\end{array}$ & $<\mathbf{0 , 0 0 1}$ & 0,08 & 0,001 & 0,017 & 0,415 & 0,125 & $<0,001$ \\
\hline $\begin{array}{l}\text { Polinkis išbandyti naujas, dar } \\
\text { nebandytas maisto prekes }\end{array}$ & 0,009 & $<0,001$ & $<0,001$ & $<0,001$ & 0,029 & 0,271 & $<0,001$ \\
\hline $\begin{array}{l}\text { Maisto produktų pasirinkimo } \\
\text { kriterijai }\end{array}$ & 0,744 & $<0,001$ & $<0,001$ & 0,03 & 0,055 & 0,622 & 0,001 \\
\hline $\begin{array}{l}\text { Kavos ar arbatos saldinimo } \\
\text { būdai }\end{array}$ & $<\mathbf{0 , 0 0 1}$ & 0,465 & 0,05 & 0,656 & 0,224 & 0,016 & 0,004 \\
\hline $\begin{array}{l}\text { Maisto produktų ar gėrimų, ku- } \\
\text { riuose yra saldiklių, vartojimo } \\
\text { dažnis }\end{array}$ & 0,003 & $<0,001$ & $<0,001$ & 0,181 & 0,031 & 0,001 & 0,001 \\
\hline \multicolumn{8}{|l|}{ Žinios apie natūralius saldiklius: } \\
\hline Fruktozė & 0,826 & 0,476 & 0,084 & $\mathbf{0 , 0 3 7}$ & 0,541 & 0,376 & 0,790 \\
\hline Stevija & $<0,001$ & 0,325 & 0,001 & 0,597 & 0,520 & $<0,001$ & 0,528 \\
\hline Medus & 0,062 & 0,598 & 0,041 & 0,004 & 0,058 & 0,016 & 0,166 \\
\hline Kukurūzų sirupas & 0,400 & 0,336 & 0,215 & 0,233 & 0,315 & 0,294 & 0,234 \\
\hline Aspartamas & 0,269 & 0,444 & 0,802 & 0,374 & 0,507 & 0,745 & 0,457 \\
\hline Sacharinas & 0,724 & 0,134 & 0,645 & 0,293 & 0,536 & 0,755 & 0,611 \\
\hline Sukralozė & 0,400 & 0,336 & 0,215 & 0,233 & 0,315 & 0,294 & 0,234 \\
\hline Cukrus & 0,002 & 0,056 & 0,685 & 0,311 & 0,260 & 0,298 & 0,446 \\
\hline Kiti & 0,216 & 0,588 & 0,015 & 0,055 & 0,486 & 0,248 & 0,019 \\
\hline
\end{tabular}

(Lentelès tęsinys kitame puslapyje) 


\begin{tabular}{|c|c|c|c|c|c|c|c|}
\hline $\begin{array}{l}\text { Maisto produktu, kurių su- } \\
\text { dėtyje yra stevijos, vartojimo } \\
\text { dažnis }\end{array}$ & 0,001 & 0,006 & 0,002 & 0,207 & 0,037 & 0,294 & $<\mathbf{0 , 0 0 1}$ \\
\hline \multicolumn{8}{|c|}{ Nuomonė apie ịvairius saldiklius (saldiklių vertinimas): } \\
\hline Stevija & $<0,001$ & 0,758 & $<0,001$ & 0,539 & 0,735 & 0,979 & 0,001 \\
\hline Aspartamas & 0,217 & 0,171 & 0,003 & 0,063 & 0,107 & 0,593 & 0,002 \\
\hline Sacharinas & 0,147 & 0,016 & 0,024 & 0,442 & 0,315 & 0,021 & $<0,001$ \\
\hline Fruktozè & 0,002 & 0,693 & 0,003 & 0,086 & 0,749 & 0,969 & 0,001 \\
\hline Sukralozè & 0,968 & 0,239 & 0,165 & 0,356 & 0,302 & 0,798 & $<0,001$ \\
\hline $\begin{array}{l}\text { Nuomonė apie natūraliụ saldi- } \\
\text { klių poveikị organizmui }\end{array}$ & 0,107 & 0,160 & $<0,001$ & 0,515 & 0,457 & 0,138 & 0,003 \\
\hline \multicolumn{8}{|c|}{ Žinojimas, kurie saldikliai yra dirbtiniai, o kurie natūralūs: } \\
\hline Fruktozé & 0,243 & 0,417 & 0,025 & 0,771 & 0,981 & 0,147 & 0,054 \\
\hline Stevija & $<0,001$ & 0,512 & $<0,001$ & 0,889 & 0,747 & 0,474 & $<0,001$ \\
\hline Medus & 0,138 & $<0,001$ & 0,170 & 0,316 & 0,688 & 0,015 & 0,238 \\
\hline Kukurūz & 0,453 & 0,300 & 0,031 & 0,356 & 0,382 & 0,996 & 0,009 \\
\hline Aspartamas & 0,159 & 0,280 & 0,521 & 0,389 & 0,549 & 0,339 & 0,918 \\
\hline Sacharinas & 0,383 & 0,088 & 0,625 & 0,927 & 0,504 & 0,614 & 0,402 \\
\hline \multicolumn{8}{|c|}{ Saldiklių vartojimo bent kartą gyvenime paplitimas: } \\
\hline Fruktozè & 0,547 & 0,168 & $<\mathbf{0 , 0 0 1}$ & $\mathbf{0 , 0 2 7}$ & 0,684 & 0,859 & 0,001 \\
\hline Stevija & 0,001 & 0,044 & $<0,001$ & 0,913 & 0,371 & 0,461 & $<0,001$ \\
\hline Medus & 0,253 & 0,308 & 0,755 & 0,052 & 0,242 & 0,203 & 0,079 \\
\hline Kukurūzų sirupas & 0,846 & 0,201 & 0,001 & 0,378 & 0,182 & 0,863 & 0,239 \\
\hline Aspartamas & 0,480 & 0,725 & 0,077 & 0,230 & 0,005 & 0,408 & 0,638 \\
\hline Sacharinas & 0,423 & 0,829 & 0,091 & 0,148 & 0,373 & 0,616 & 0,032 \\
\hline Sukralozè & 0,236 & 0,244 & 0,347 & 0,251 & 0,289 & 0,454 & 0,256 \\
\hline
\end{tabular}

išsimokslinimą turintys respondentai (atitinkamai $12,5 \%$ prieš $6,1 \%, 14,1 \%$ prieš $9,5 \%$ ). Apie fruktozę geros nuomonès buvo daugiau moterų, negu vyrų (29,5\% prieš $25,9 \%)$ ir miesto gyventojų $(28,4 \%$ prieš $26,5 \%)$. Sukralozę neigiamai vertino aukštesnị išsimokslinimą turintys apklaustieji $(9,3 \%$ prieš $6,1 \%)$.

Natūralūs saldikliai dažniau buvo vertinami kaip turintys labiau teigiamą $(39,8 \%)$, nei neigiamą (32,0\%) poveikị. Buvo respondentų (10,9\%), maniusių, kad natūralūs saldikliai neturi jokio poveikio, kai kurie $(17,3 \%)$ apie saldiklių poveikį nežinojo. Miesto gyventojai ir labiau išsimokslinę asmenys natūralių saldiklių poveikị vertino labiau teigiamai negu neigiamai (atitinkamai 32,2\% prieš $23,7 \%, 34,2 \%$ prieš $28,3 \%$ ). Žemesnio išsimokslinimo asmenys dažniau manè, kad natūralūs saldikliai neturi jokio poveikio organizmui $(12,0 \%$ prieš $8,2 \%)$.

Natūraliu saldikliu dažniausiai buvo laikomas medus (94\%), rečiau - fruktozė $(45,8 \%)$, kukurūzų sirupas $(32,7 \%)$, stevija $(25,2 \%)$, sacharinas $(7,8 \%)$, aspartamas $(2,7 \%)$. Medų, kaip natūralų saldiklį, pasirinko vyresni ir turintys partnerị asmenys (atitinkamai $96,9 \%$ prieš $91,1 \%, 95,5 \%$ prieš $91,2 \%$ ). Fruktozę dažniau rinkosi miesto nei kaimo gyventojai (48,0\% prieš 40,1\%). Prie natūralių saldiklių steviją dažniausiai priskyrė moterys, didmiesčiu gyventojai ir aukštesnio išsimokslinimo asmenys (atitinkamai $31,9 \%$ prieš $17,3 \%, 29,5 \%$ prieš $14 \%, 34,2 \%$ prieš $22 \%$ ). Kukurūzų sirupą, kaip natūralų saldiklį, dažniausiai ịvardijo miesto gyventojai bei turintys aukštesni išsimokslinimą asmenys (atitinkamai $34,7 \%$ prieš $27,6 \%, 39 \%$ prieš $30,3 \%$ ).

Dauguma respondentų $(78,1 \%)$ nurodè bent kartą gyvenime ragavę medaus. Fruktozès ragavo mažiau nei pusė apklaustųju $(43,4 \%)$, dar mažiau nurodè ragavę sacharino

(30,9\%), stevijos (18,2\%), sukralozės $(3,4 \%)$, kukurūzų sirupo $(9,5 \%)$, aspartamo $(9 \%)$. Fruktozę bent kartą gyvenime ragavo didesnè dalis miesto gyventojų $(47,3 \%$ prieš $33 \%)$, dirbančių $(45,3 \%$ prieš $37,4 \%)$ ir aukštesni išsimokslinimą igijusių asmenų (52\% prieš $40 \%)$. Steviją dažniau ragavo moterys, jaunesni asmenys, labiau išsimokslinę ir didmiesčių gyventojai (atitinkamai $22 \%$ prieš $13,6 \%, 20,6 \%$ prieš $15,8 \%, 28,3 \%$ prieš $14,4 \%$, $20,9 \%$ prieš $11,1 \%$ ). Kukurūzų sirupas labiau paplitęs tarp miesto gyventojų $(11,4 \%$ prieš $4,7 \%$ ), o aspartamas - tarp didesnes pajamas uždirbančių asmenų (14,2\% prieš $7,8 \%)$. Sachariną bent kartą gyvenime dažniau ragavo aukštesnị išsimokslinimą igiję asmenys (36,1\% prieš $29 \%$ ) (2 lentelè).

\section{Rezultatų aptarimas}

Tyrimo rezultatai atskleidè, kad ịvairūs socialiniai ir demografiniai veiksniai susiję su reikšmingais maisto produktų etikečių skaitymo bei cukraus ir saldiklių vartojimo skirtumais Lietuvoje. Gyvenamosios vietos tipas, igytas išsimokslinimas bei lytis dažniausi veiksniai, lemiantys etikečiu skaitymo, cukraus ir saldiklių vartojimo netolygumus. Rečiau stebèti reikšmingi skirtumai, priklausomi nuo amžiaus, užimtumo, gaunamų pajamų bei šeiminès padèties. Dažniausiai netolygumai pagal socialinius ir demografinius veiksnius stebeti polinkio išbandyti naujas, dar nebandytas maisto prekes bei maisto produktų ar gèrimų, kuriuose yra saldiklių, dažnio atveju. Respondentų nuomonè dažniausiai skyrèsi stevijos ir 
fruktozès vartojimo atvejais. Šio tyrimo rezultatai tik iš dalies atitiko JAV tyrimo rezultatus, atskleidusius, kad saldiklių vartojimas skyrèsi priklausomai nuo igyto išsimokslinimo, amžiaus ir gaunamų pajamų, t.y. veiksnių, kurie Lietuvoje su skirtingu saldiklių vartojimu susiję rečiau [4].

Remiantis mūsų tyrimo rezultatais, kaip natūralius saldiklius Lietuvos gyventojai dažniausiai įvardijo medų bei fruktozę. Beveik pusė Lietuvos gyventojų nežinojo saldiklio stevijos $(45,7 \%)$. Dažniau šio saldiklio nežinojo žemesnio išsimokslinimo respondentai. Kaip natūralų saldiklị steviją įvardijo 25,2 proc. apklaustujų (dažniausiai moterys, didmiesčių gyventojai ir aukštesnio išsimokslinimo asmenys). Fruktozès nurodė ragavę beveik pusė apklaustujų $(43,4 \%)$, stevijos - tik penktadalis $(18,2 \%)$. Fruktozè buvo labiau paplitusi tarp miesto gyventojų, dirbančių ir aukštesni išsimokslinimą igijusių asmenų. Steviją ragavusios dažniau nurode moterys, jaunesni asmenys, labiau išsimokslinę ir didmiesčių gyventojai. Lietuvos gyventojų saldiklių vartojimas skiriasi nuo kaimyninės šalies Lenkijos gyventojų saldiklių vartojimo: 2019 metų duomenimis, Lenkijoje dažniausiai vartojami saldikliai - stevija $(41,8 \%)$, ksilitolis $(23,6 \%)$ ir aspartamas (15,6\%). Skirtingai nuo Lietuvos, fruktozè Lenkijoje buvo rečiau vartojamas saldiklis $(12,3 \%)$. Saldiklių vartojimas tarp Lietuvos gyventoju mažiau paplitęs, nei tarp Lenkijos gyventojų. Lenkijoje iš viso saldiklius vartojo 39,8 proc. gyventojų, iš kurių 18,5 proc. - reguliariai, 21,75 proc. - retkarčiais. Lietuvoje bent kartą per savaitę saldiklius nurodè vartojantys 33,9 proc., saldikliais kavą ar arbatą saldinantys tik 2,5 proc. gyventojų. Cukraus vartojimas tarp Lietuvos ir Lenkijos gyventojų dažnesnis, nei saldiklių: dauguma Lenkijos gyventojų $(52,9 \%)$ nurodè cukrų vartojantys reguliariai, trečdalis $(34,5 \%)$ - retkarčiais; Lietuvoje kavą ar arbatą cukrumi saldina daugiau kaip pusė (55,3\%) gyventojų. Abiejose šalyse cukraus vartojimas labiau paplitęs tarp vyrų, tačiau Lenkijoje cukraus vartojimas labiau paplitęs tarp kaimo vietovėse gyvenančių asmenų, o Lietuvoje - tarp žemesnio išsimokslinimo gyventojų. Saldiklių vartojimas Lenkijoje dažnesnis tarp jaunesnio amžiaus, aukštesnį išsimokslinimą ịgijusių, didmiesčiuose gyvenančių bei didesnes pajamas gaunančių asmenų [19].

Skirtingai nuo mūsų tyrimo rezultatų, JAV atliktas tyrimas parodè, kad dažniausiai saldiklius vartojo 55-64 metu gyventojai $(39,4 \%)$, mažiausias susidomejjimas jais buvo stebimas tarp 20-24 metų JAV gyventojų (12,5\%). Dažniau juos vartojo JAV gyvenančios moterys $(34,0 \%$ lyginant su $25,5 \%$ vyrų), didžiausias pajamas gaunantys ( $35,8 \%$ lyginant su $19,6 \%$ mažesnes pajamas gaunančiu), igiję aukštesni išsimokslinimą (37,4\% lyginant su $17,3 \%$ žemesnio išsimokslinimo respondentų). Pasak JAV atlikto tyrimo auto- rių, saldiklių vartojimo netolygumus galèjo nulemti tyrimo dalyvių noras sumažinti pridètinio cukraus vartojimą, ji pakeičiant mažiau kaloringais saldikliais [20]. Kaip ir JAV, Australijoje saldiklius dažniau rinkosi vyresni gyventojai ir moterys. Saldiklių vartojimas Australijoje buvo dažnesnis tarp žemiausios socioekonominès padèties asmenų (19,4\% prieš $17,6 \%$ ) ir aukštesnị išsimokslinimą ịijusių gyventojų (18,6\% prieš $18,3 \%$ ). Australijoje atlikto tyrimo autoriai atkreipe dèmesị ir ị kitus, skirtingą saldiklių vartojimą galinčius nulemti veiksnius. Nustatyta, kad dažniau saldiklius vartojo nutukę (25,7\% lyginant su $12,6 \%$ normalaus svorio grupejje), fiziškai aktyvūs (19,1\% prieš $17,4 \%)$, sergantys cukriniu diabetu (38,4\% prieš $17 \%$ ), besilaikantieji dietos $(35,1 \%$ prieš $17 \%)$ bei nerūkantys gyventojai $(18,4 \%$ prieš 17,3\%). Australijoje saldiklius dažniau rinkosi gyventojai, kurie turejo sveikatos problemų, rūpinosi savo mityba bei svoriu [21]. JAV atliktas tyrimas taip pat parodè, jog saldiklius dažniau rinkosi nutukę, turintieji padidejusią cholesterolio koncentraciją kraujyje bei arterine hipertenzija ir cukriniu diabetu sergantys gyventojai [20, 22].

Ispanijoje atlikto tyrimo duomenimis, etikečių skaitymas gali būti susijęs su maisto produktų pasirinkimu. Kaip atskleide pastarasis tyrimas, renkantis maisto produktus lytis ir amžius nebuvo reikšmingi veiksniai, tačiau nustatyta, jog etikečių dažniau neskaitè žemesnio išsimokslinimo asmenys ( $40 \%$ prieš $2 \%$ ). Daugiau kaip pusè iš jų (53\%) niekada neatsižvelgdavo ị pridètinio cukraus ar kalorijų kiekị. Tyrimo autoriai nustate, jog žemesnio išsimokslinimo asmenų grupe etiketėse esančią informaciją laikè per daug technine $(53 \%$ prieš 4\%) [23]. Mūsų tyrimo rezultatai panašūs: dažniau etiketes skaitė aukštesnio nei žemesnio išsimokslinimo respondentai (atitinkamai 36,4\% ir 22,4\%). Be to, skirtingai nuo Ispanijoje atlikto tyrimo, Lietuvoje etiketes dažniau skaitė moterys, dirbantys asmenys bei didmiesčiu gyventojai.

\section{Išvados}

Gyvenamosios vietos tipas, igytas išsimokslinimas bei lytis - dažniausi veiksniai, lemiantys etikečiu skaitymo, cukraus ir saldiklių vartojimo netolygumus.

Dauguma gyventojų kaip žinomus ir ragautus saldiklius nurodè medų ir fruktozę, o svetur dažnai vartojamo saldiklio - stevijos nežinojo beveik pusè Lietuvos gyventojų.

\section{Literatūra}

1. World Health Organization. WHO calls on countries to reduce Sugars intake among adults and children 2015. https://www. who.int/mediacentre/news/releases/2015/sugar-guideline/en/

2. Lietuvos Respublikos Seimo2014 m. birželio $26 \mathrm{~d}$. Nutarimas dèl Lietuvos sveikatos 2014-2025 metų strategijos patvirtinimo. 
Nr. XII-964.

3. Martínez-Carrillo BE, Rosales-Gómez CA, Ramírez-Durán N, Reséndiz-Albor AA, Escoto-Herrera JA, Mondragón-Velásquez $\mathrm{T}$, et al. Effect of chronic consumption of sweeteners on microbiota and immunity in the small intestine of young mice. IntJ Food Sc 2019(4):1-16.

https://doi.org/10.1155/2019/9619020

4. Sylvetsky AC, Rother KI. Trends in the consumption of lowcalorie sweeteners. PhysiolBehav 2016;164:446-450.

https://doi.org/10.1016/j.physbeh.2016.03.030

5. Anderson GH, Foreyt J, Sigman-Grant M, Allison DB. The use of low-calorie sweeteners by adults: impact on weight management. J Nutr 2012;142(6):1163s-1169s.

https://doi.org/10.3945/jn.111.149617

6. O'Brien-Nabors L (Ed.). Alternative sweetener. Fourth Edition. USA, CRC Press Taylor and Francis Group 2016:587.

7. Paglia L. The sweet danger of added sugars. Eur J Paediatr Dent 2019;20(2):89-89.

8. Chattopadhyay S, Raychaudhuri U, Chakraborty R. Artificial sweeteners - a review. J Food Sci Technol 2014;51(4):611-621. https://doi.org/10.1007/s13197-011-0571-1

9. Choudhary AK, Pretorius E. Revisiting the safety of aspartame. Nutr Rev 2017;75(9):718-730. https://doi.org/10.1093/nutrit/nux035

10. Choudhary AK, Lee YY. Neurophysiological symptoms and aspartame: What is the connection? Nutr Neur 2018;21(5):306316.

https://doi.org/10.1080/1028415X.2017.1288340

11. Ardalan MR, Tabibi H, Attari VE, Mahdavi AM. Nephrotoxic effect of aspartame as an artificial sweetener: a brief review. Iran J Kidney Dis 2017;11(5):339-343.

12. Pearlman M, Obert J, Casey L. The association between artificial sweeteners and obesity. Curr Gastroenterol Rep 2017;19(12):64. https://doi.org/10.1007/s11894-017-0602-9

13. Anderson GH, Foreyt J, Sigman-Grant M, Allison DB. The use of low-calorie sweeteners by adults: impact on weight management. J Nutr 2012;142(6):1163s-1169s.

https://doi.org/10.3945/jn.111.149617

14. Christides T, Sharp P. Sugars increase non-heme iron bioavailability in human epithelial intestinal and liver cells. PloS one 2013;8(12):e83031.

https://doi.org/10.1371/journal.pone.0083031

15. Buzás GM. Fructose and fructose intolerance. Orv Hetil 2016;157(43):1708-1716.

https://doi.org/10.1556/650.2016.30567

16. Chen Q, Wang T, Li J, Wang S, Qiu F, Yu H, et al. Effects of natural products on fructose-induced nonalcoholic fatty liver disease (NAFLD). Nutr 2017;9(2):96. https://doi.org/10.3390/nu9020096

17. Ulbricht C, Isaac R, Milkin T, Poole EA, Rusie E, Grimes Serrano JM, et al. An evidence-based systematic review of stevia by the natural standard research collaboration. Cardiovasc Hematol Agents Med Chem 2010;8(2):113-127.

https://doi.org/10.2174/187152510791170960

18. Anderson J, Young L. Sugar and sweeteners. Health 2005.

19. Pielak M, Czarniecka-Skubina E, Trafiałek J, Głuchowski A. Contemporary trends and habits in the consumption of sugar and sweeteners - a questionnaire survey among poles. Int J Environ Res Public Health 2019;16(7):1164.

https://doi.org/10.3390/ijerph16071164

20. Drewnowski A, Rehm C. Consumption of low-calorie sweeteners among US adults is associated with higher healthy eating index (HEI 2005) scores and more physical activity. Nutr 2014;6(10):4389-4403.

https://doi.org/10.3390/nu6104389

21. Grech A, Kam C, Gemming L, Rangan A. Diet-quality and socio-demographic factors associated with non-nutritive sweetener use in the Australian population. Nutr 2018;10(7):833. https://doi.org/10.3390/nu10070833

22. Jin Y, Sylvetsky AC, Kandula NR, Kanaya AM, Talegawkar SA. Prevalence of low-calorie sweetener intake in South Asian adults. Nutr Health 2018;24(4):203-209.

https://doi.org/10.1177/0260106018792409

23. Carrillo E, Varela P, Fiszman S. Influence of nutritional knowledge on the use and interpretation of Spanish nutritional food labels. J Food Sci 2012;77(1):H1-H8.

https://doi.org/10.1111/j.1750-3841.2011.02479.x

\section{ASSESSMENT OF LITHUANIAN RESIDENTS' OPINION ON ADDED SUGAR AND SWEETENERS \\ R. Stukas, R. Arlauskas, I. Lingytė, V. Dobrovolskij, D. Austys}

Keywords: sweeteners, residents of Lithuania, adults.

Summary

Background. In order to reduce prevalence of overweight, obesity and related diseases, Lithuania and many other countries are trying to reduce the amount of added sugar in foods. Reducing sugar consumption is likely to increase the consumption of sweeteners. Like sugar, they are associated with multiple health effects. Consumption of sugar and sweeteners varies with respect to social and demographic factors across the world. There is a lack of studies on the consumption and attitudes towards consumption of sweeteners in Lithuania, therefore, the aim of this study was to assess that in the Lithuanian population with respect to social and demographic characteristics.

Methods. A representative sample of the Lithuanian population was formed. A total of 1008 respondents aged 18 to 75 participated. Data were collected using a questionnaire. Food choices, intake of sugar and sweeteners, and knowledge about sweeteners where analyzed with respect to social and demographic characte- 
ristics of the population.

Results. Type of residence, education and gender were the most common factors determinants of consumption of sugar and sweeteners, practice of reading labels. The majority of rural population did not read labels, chose foods by price, did not care about its ingredients $(20.4 \%$ vs. $12.3 \%, 28.3 \%$ vs. $17.3 \%, 35.5 \%$ vs. $20.4 \%$, respectively, $\mathrm{p}<0.05)$. Urban residents were more likely to try new products and more likely to appreciate the effects of natural sweeteners on the body than rural residents $(17.3 \%$ vs. $9.7 \%, 32.2 \%$ vs. $23.7 \%$, respectively, $\mathrm{p}<0.05)$. Lower educated individuals were less likely to be concerned about ingredients of their foods and were more likely to think that natural sweeteners had no effect on the body $(27.9 \%$ vs. $16.0 \%, 12.0 \%$ vs. $8.2 \%$, respectively, $\mathrm{p}<0.05)$. Higher educated respondents were more likely to read food labels, try new products and choose foods based on their quality $(36.4 \% \mathrm{vs}$. $22.4 \%, 20.4 \%$ vs. $13.3 \%, 12.6 \%$ vs. $10.2 \%$, respectively, $\mathrm{p}<0.05)$.
Men were less likely to read labels or concern about ingredients of their foods $(21.2 \%$ vs. $9.0 \%, 28.9 \%$ vs. $20.9 \%$, respectively, $\mathrm{p}<0.05)$. Women were more likely to try new foods $(49.5 \% \mathrm{vs}$. $42.1 \%, \mathrm{p}<0.05)$. Honey, fructose and saccharin were the most prevalent sweeteners in Lithuania $(78.1 \%, 43.4 \%$ and $30.9 \%$, respectively). Almost half (45.7\%) of respondents were unaware of stevia.

Conclusion. Type of residence, education and gender were the most common determinants of consumption of sugar and sweeteners, practice of reading labels. Honey and fructose were the most prevalent sweeteners but almost half of the Lithuanian population did not know stevia which is commonly used sweetener abroad.

Correspondence to: Rimantas.Stukas@mf.vu.lt

Gauta 2019-11-15

\section{KVIEČIAME PRENUMERUOTI "SVEIKATOS MOKSLŲ" ŽURNALĄ 2020 METAIS!}

Žurnalas "Sveikatos mokslai" (Index Copernicus, EBSCO host (Academic Search Complete), Gale (Academic OneFile), ProQuest (Ulrich's, Summon), Australia (ERA) 2012 Journal List (ERA ID 34962) skirtas visų specialybių gydytojams, slaugytojams ir kitiems specialistams, spausdina mokslinius straipsnius lietuvių, anglų kalbomis. Reikalavimai straipsniams atitinka mokslo leidiniams keliamus reikalavimus. Žurnalas kioskuose neparduodamas. Žurnalą, kuris leidžiamas kartą per du mènesius, galima užsiprenumeruoti visuose Lietuvos pašto skyriuose, taip pat internetu: www.prenumeruok.lt

Prenumeratos kaina nesikeičia: visiems metams - 36 EUR, šešiems mėnesiams - 18 EUR, keturiems mẻnesiams - 12 EUR, dviem mėnesiams - 6 EUR. Prenumeratos kodas: 5348.

Žurnalo autoriams straipsnių spausdinimas mokamas.

Redakcija 